\title{
The Effect of Ethnic Factor on Cephalic Index in 17-20 Years Old Females of North of Iran
}

\author{
Efecto del Factor Étnico en el Índice Cefálico en Mujeres \\ entre 17 y 20 Años de Edad del Norte de Irán
}

Mohammad Jafar Golalipour

GOLALIPOUR, M. J. The effect of ethnic factor on cephalic index in 17-20 years old females of North of Iran. Int. J. Morphol., 24(3):319-322, 2006.

SUMMARY: Cephalic index and head shape are affected by geographical, gender, age, racial and ethnic factors. This study was carried out to determine cephalic index and head shape in 17-20 years old female in Gorgan, North of Iran.

This descriptive and cross sectional study is undertaken on 410 normal 17-20 years old female (Turkman group: n=203, Fars group: $\mathrm{n}=207$ ). The study was done by classic cephalometry in Gorgan - North of Iran.

Means and SD of cephalic index was $85 \pm 4.5$ and $82.8 \pm 3.6$ in native Fars and Turkman groups, respectively. Dominant and rare type of head shape in native Fars group were hyperbrachycephalic (53.6\%) and dolichocephalic (15\%), and in Turkman group were brachycephalic $(58.1 \%)$ and dolichocephalic $(0.05 \%)$, respectively.

With noticing of our results and other studies in the world, we can conclude that the role of ethnic factor on head dimensions.

KEY WORDS: Craniofacial forms; Cephalometry; Cephalic index; Female.

\section{INTRODUCTION}

The study of the craniofacial relations and variations in man has long been used to different various racial groups in physical anthropology. Morphology features of different races and ethnic groups aren't randomly distributed but appear in geographic clusters (Argyropoulos \& Sassouni, 1989).

The method currently availed craniofacial form include anthropometry, photogramentry, cephalometry, ultrasound, computed tomographic (CT) scanning magnetic imaging (MRI) and optical surface scanning (Grant \& Peter 2003).

Arguably, cephalometry continues to be the most versatile technique in the investigation of the craniofacial skeleton because of its validity and practicality (Grant \& Peter).

The name cephalometry is grain to the morphological study of all the structures present in a human head (Grau et al., 2001).
This study is carried through the measurement of distances between significant structures. Campration of the measurements with the standards for the same age, race, and sex is a valuable tool for diagnosis, treatment monitoring and prediction of orthodensy treatment results (Grau et al.).

Cephalometry is the scientific measurement of the dimensions of the head, usually through the use of standardized lateral skullradiographsor cephalograms (ElFeghi et al., 2004).

On the basis of above factors, anthropometrics studies are conducted on the age, sex and racial/ethnic groups in certain geographical zones (Williams et al., 1995, del Sol 2005, Shah \& Jadhav 2004, Golalipour et al., 2003, Golalipour et al., 2005).

The most important of cephalometric dimension are height and weigh of head that with them determine cephalic index. 
On basis of cephalic index head shapes group to four international categories, that including dolichocephal, brachycephal, mesocephal and hyperbrachycephal (Williams et al. and del Sol).

A few investigations carried out on were done to determine the type of head shape in various ages in Iran and other countries (Golalipour et al., 2003; del Sol and Shah \& Jadhav).

With noticing, the effect of racial, ethnic and geographical factors on head dimensions and lack of documented research about 17-20 years old female in this area, this study was done to determine the cephalic index and the types of head shapes in 17-20 years old female in Gorgan- North of Iran.

\section{MATERIAL AND METHOD}

This descriptive and cross sectional research was done on 410, 17-20 years old normal female (Fars group $\mathrm{n}=207$; Turkman group, $\mathrm{n}=203$ ).

Turkman group: Turkmans populations are living in more than two centuries ago in this area, who imigrated from central Asia. Turkman people are only marrying in intra -group because of religious and ethnic beliefs.

Native Fars group: are main and original inhabitants of this region and populations of native Fars has been selected last three generations who lived in this zone.

All the measurements were taken with the subject sitting in chair, in relaxed condition and head in anatomical position.

Head measurements, which were determined by Martin spreading caliper, were included:

- Head length = Summit of glabella to furthest occipital point. - Head width $=$ greats breadth, at right angles to median plane.

$$
\frac{\text { Head width }}{\text { Head length }} \times 100=\text { cephalic index }
$$

Above index were determined on the basis of international anatomical descriptive (Williams et al.).

Depending upon this index, the types of head shapes were followed as (Williams et al.).
Head shape

Dolichocephalic

Mesochepalic

Brachycephalic

Hyperbrachycphalic

Cephalic index $(\mathrm{CI})$ range $(\%)$

CI $<74.9$

$75<\mathrm{CI}<79.9$

$80<\mathrm{CI}<84.9$

$85<\mathrm{CI}<89.9$ and $\mathrm{CI}<89.9$

The data for each person was recorded in a special form and then analyzed by EPI6.

For determining morphological index in two groups, we used Chi-square test and for comparison of the means of anthropometric measurements $\mathrm{T}$ student test $(\mathrm{a}=0.05)$ was used.

\section{RESULTS}

Means and SD of cephalic index in Turkman and native Fars group were $82.8 \pm 3.6$ and $85 \pm 4.5$, respectively.

Head was classified by cephalic index, so that hyperbrachycephalic type with $53.6 \%$ was dominant and dolichocephalic type with $0.1 \%$ was rare in native Fars females (Table I).

Dominant and rare types in Turkman group were brachycephalic $(58.1 \%)$ and dolichocephalic $(0.5 \%)$, respectively (Table 1).

Table I. Distribution of head shape in Turkman and native Fars female in 17- 20 years old.

\begin{tabular}{lccc}
\hline Head shapes & $\begin{array}{c}\text { Turkman } \\
\mathbf{N}^{\circ} \text { (percent) }\end{array}$ & $\begin{array}{c}\text { Native Fars } \\
\mathbf{N}^{\circ} \text { (percent) }\end{array}$ & p-Value \\
Dolichocephal & $1(0.5)$ & $2(0.1)$ & NS* \\
Mesocephal & $27(13.3)$ & $19(9.2)$ & NS* \\
Brachycephal & $118(58.1)$ & $75(36.2)$ & 0.0001 \\
Hyperbrachycphal & $57(28.1)$ & $111(53.6)$ & 0.0001 \\
\hline
\end{tabular}

*NS: Not significant

\section{DISCUSSION}

In this study cephalic index in native Fars group was 85. This finding was higher than Abolhasanzadeh study in Tehran- center of Iran with 75 (Abolhasanzadeh \& Farahani; 2003), and Shah Report from India with 81.20 (Shah \& Jadhav). 
The cephalic index in Turkman group was 82.8. The cephalic index in this group was higher than other report in Iran with 75 (Abolhasanzadeh \& Farahani), Shah Report with 81.20 (Shah \& Jadhav) and Nakashima study on rural woman with 81 , but was lower than Nakashima study on female students with 87 (Nakashima, 1986) and native Fars group with 85 in this study.

In our study, the dominant type of head shape in native Fars group was hyperbrachycephalic (53.6\%). This finding is not similar to other study in Iran (Abolhasanzadeh \& Farahani) that the dominant type was brachycephalic $(42.7 \%)$ and Shah study in India on female students (Shah \& Jadhav).

Also, the dominant type of head from this study is not similar to other study that were done on males such as in India (Bhatia et al., 1995) (dolicocephal 58.5\%), del Sol study in Chile and other study (Marquer \& Chamela, 1961).

Also,the dominant type of head form in Turkman groups was brachycephalic that is similar to Abolhasanzadeh and Farahani, 2003 and Shah report (Shah \& Jadhav, 2004), on female students and it is in contrast with the finding of this study in native Fars group.

Shah \& Jadhov on 198 female in India reported that dolichocephal was $3 \%$, mesocephal 39.4 , brachycephal $49 \%$ and hyperbrachycephal $21.7 \%$.

In other study was done on 759 adult female (2224 years old) in Tehran- Iran in 2003, reported that 42.7 $\%$ of the individuals were brachycephalic, $22.9 \%$ hyperbrachycephalic, $24.5 \%$ mesocephalic and $9.9 \%$ dolichocephalic.

More than eight centuries ago, the two studies were done by to famous scientists in Iran, that the findings of these researches are very interesting (Avicenna and Jorjani 1975).

Avicenna and Jorjani reported that the dominant type of head shape in Iranian people was mesocephal, but in recent studies in Iran the dominant type were hyperbrachycephalic or brachycephalic.

Therefore, we concluded that there is a trend changes in head shapes of Iranian people, which it means that the dominant of head shape has changed from monocephalic to brachycephalic and hyperbrachyphalic.

Other study showed a trends changes of head shape (brachycephalization) during 30 years in Japanese people (Nakishima).

Of course, the previous study on female newborns indicated that the dominant type of head was mesocephalic (Golalipour et al., 2005)

With noticing to above study (Golalipour et al., 2003) and other study (El-Feghi et al.) it is possible that the changes of age can influence the head shape.

In respect to the variation of head shape in various races and geographical zones, we believe that in hereditary factor primarily affects on the shape of head, however environment has secondary effect on it.

It must be remembered that the reaction to a given environment represents the interaction of the genotype of the population being studied with the environment (Jordaan, 1976).

With noticing to present study and other Iranian study we can conclude that process of brachycephalization and hyperbrachycephalization was happened during some centuries on consequents of people.

GOLALIPOUR, M. J. Efecto del factor étnico en el índice cefálico en mujeres entre 17 y 20 años de edad del Norte de Irán. Int. J. Morphol., 24(3):319-322, 2006.

RESUMEN: El índice cefálico y forma de la cabeza son afectados por factores geográficos, género, edad, raza y grupos étnicos. Este estudio determina el índice cefálico y la forma de la cabeza en mujeres entre 17 y 20 años de edad en Gorgan, Norte de Irán.

El estudio fue realizado en 410 mujeres normales de17 a 20 años de edad (grupo Turco n=203, grupo Fars n=207) del Norte de Irán, a través de cefalometría clásica.

La media y DS del índice cefálico fue $85 \pm 4.5$ y $82.8 \pm 3.6$ en nativos de los grupos Fars y Turcos, respectivamente. Tipos dominantes y raros de la forma de la cabeza en el grupo Fars fueron hiperbraquicefálico (53.6\%) y dolicocefálico (15\%), y en el grupo Turco fueron braquicefálico $(58.1 \%)$ y dolicocefálico $(0.05 \%)$, respectivamente. Estos resultados y el de otros estudios realizados en el mundo, permiten concluir la influencia que tienen los factores étnicos en las dimensiones de la cabeza. 
ACKNOWLEDGEMENTS: We appreciate the research deputy of Gorgan University of Medical Sciences, and Mr. K. Heidari, Mr. M. Jahanshahi and Mr M. A.Vakili for statistical analysis and Miss Soraya Ghafari for her helpings and Special thanks to Dr A. Rayej.

\section{REFERENCES}

Abolhasanzadeh, A. \& Farahani, M.R. Standarded international classification of head shapes of 22-24 years old in Tehran. J. of Research in medicine, 26(4):281-5, 2003.

Argyropoulos, E. \& Sassouni, V. Comparison of the dentofacial patterns for native Greek and AmericanCaucasian adolescents. Am. J. of orthodontics and dentofacial orthopedics, 95:238-49, 1989.

Avicenna, Sh.R. Law in medicine (Ghanon dar teb). Translated to persian (Farsi) by Sharafkandi, A.r. Sorosh publisher co.Tehran, 1984. V. 1. p. 57.

Bhatia, M.; Thin, J.; Debray, H. \& Cabanes, J. Etude anthropologique et genetique de la population du nord de l'Inde. Bull. Et Mem. Soc. d'anthrop. de Paris, 10(6):199-213,1955.

Del Sol, M. Cephalic index in a group of mapuche individuals in the IX Region of Chile. Int. J. Morphol., 23(3):241-6, 2005.

El-Feghi, I.; Sid-Ahmad, M. A. \& Ahmadi, M. Automatic localization of craniofacial landmarks for assisted cephalometry. Pattern Recognition, 37:609-21, 2004.

Golalipour, M. J.; Haidari, K.; Jahanshahi, M. \& Frahani, M. R. The shapes of head and face in normal male newborns in south-east of Caspian Sea (Iran-Gorgan). J. Anat. Soc. India, 52:28-31, 2003.

Golalipour, M. J.; Jahanshahi, M. \& Haidari, K. The variation of head and face shapes in female newborns in the South-East of the Caspian Sea (Iran-Gorgan). Eur. J. Anat., 9(2):95-8, 2005.

Grant, T. M. \& Peter, A. M. Size and shape measurement in contemporary cephalimeyrics, Eur. J. of orthodontics. 25(3):231-42, 2003.

Grau, V.; Alcaniz, M.; Juan, M.C.; Monserrat, C. \& Knoll, C. Automatic localization of cephalometric landmarks.
J. of Biomedical Informatics, 34:146-56, 2001.

Jordaan, H. V. Neonatal and maternal cranial form. S. Afr. Med. J., 4(52):2060-8, 1976.

Jorjani, S. I. Zakhireye Khrazmshahi. Translated to Persian by: Sirjani Saidi. Iranian cultural institute. Tehran, 1975. p. 17.

Marquer, P. Chamela M. C. L'evolution des caracteres morphologiques en function de l'age, chez 2089 fracais, de 20 a 91 ans. Bull. et Mem. Soc. d'anthrop. de Paris, 11(2):1-78, 1961.

Nakashima, T. Brachycephalization in the head form of school girls in north kyuoshu. Sangyo. Ika Dainguku Zussshi. 8(4):411-4, 1986.

Shah, G.V. \& Jadhav, H. R. The study of cephalic index in students of Gujarat. J. Anat. Soc. India, 53(1):25-6, 2004.

Williams, P.; Dyson, M.; Dussak, J. E.; Bannister, L. H.; Berry, M.M.; Collins, P. \& Ferguson, M. W. J. Gray's anatomy. In. Skeletal system. $38^{\text {th }}$ Edn.; Elbs with Churchill Livingston, London, 1995. pp. 607-12.

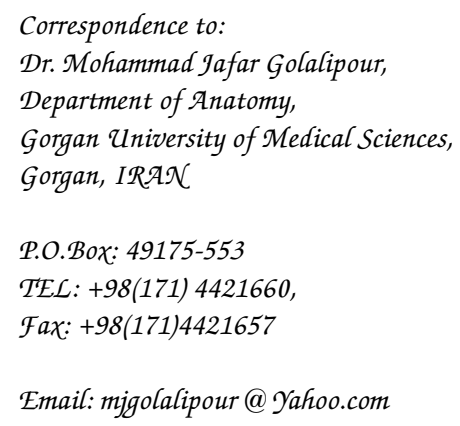

Received: 23-12-2005 Accepted:16-05-2006 